\title{
A Classic Case of Horrible Family Violence Where the Father Tried To Kill His Children - Dynamics of the Relationship between the Perpetrator and the Victim in Forensic Psychiatric Examination
}

\author{
Siniša Franjić*
}

Faculty of Law, International University of Brcko District, Brcko, Bosnia and Herzegovina, Europe.

\begin{abstract}
On February 28, 2019, something terrible happened on the island of Pag, Croatia. A man at the age of 54 at 6:30 in the morning dropped his four little children from the first floor of the house down to the concrete; he threw them down from six meters high. Children are three, five, seven and eight years old. The scene was terrible: Four kids lay on concrete in the blood pools and everyone who saw it was shocked. All children have suffered injury, and the most seriously injured was 7-year-old girl who has been operated and successfully recovering. This case is one of the most horrible forms of family violence.
\end{abstract}

Keywords: Children; Father; Crime; Attempted homicide

\section{INTRODUCTION}

What is the relationship between attempting and acting [1]? The question can be approached from two directions. First, in what way is attempting a species of intentional action more generally? Second, what is the role of acting in attempting?

Actions are constituted by an actor's knowledge, understanding, beliefs, hopes, fears, reasons for acting, physical movements and from the relation of all this to facts in the world. (Attempts have the same, rich ontological roots.) It follows that we do not have a somewhat distant relationship to what we do, in the order of mind to act. Rather, what we do is given substance by the capacities (mental and others) that we bring to action. This concept of action has important implications for criminal law. Most notably, it is incompatible with the division between mens rea and actus reus that classically characterises offences, a division that is particularly troublesome for criminal attempts. Here the unity between actus reus and mens rea will be identifed. Against their shared rich ontology, how are actions, and attempts as actions, to be distinguished? The distinction turns out to be a descriptive one; conceiving of an action as an attempt reflects a subjective purpose, to account only for what an actor sets out to do, his reason for acting.

\section{Inchoate liability}

Attempt liability is a form of inchoate liability [2]. A criminal need not complete a crime in order to be convicted. If he tries to commit the crime but fails, the law calls this a "complete attempt" and he can still be prosecuted and punished. If he starts the crime but is caught by the police before he finishes, the law calls this an "incomplete attempt" and he is also subject to criminal liability. Indeed, society wants to give police officers the incentive to intervene in a burgeoning criminal endeavour and prevent the perpetrator from consummating the offense. If intervention and thwarting the crime was a bar to prosecution, the police would wait for the criminal to finish before catching him-hardly a desirable result for the victim. Generally speaking, the requirements for a punishable attempt are that (i) the defendant has the specific intent or purpose to bring about the crime and that (ii) he starts committing the crime. Then, two defences might apply if (iii) the crime is impossible to complete or (iv) the defendant abandoned the effort.

An attempted crime occurs when a person intends to commit a specific offense and then performs an act that constitutes a substantial step toward consummating that offense [3]. Although attempts do not bring about tangible harm, conduct that manifests criminal intent may disturb the public repose or cause apprehension,

Correspondence to: Siniša Franjić, Faculty of Law, International University of Brcko District, Brcko, Bosnia and Herzegovina, Europe, Tel: +387-49-49-04-60. E-mail:sinisa.franjic@gmail.com

Received: July 12, 2018, Accepted: September 02, 2019, Published: September 09, 2019

Citation: Franjić S (2019) A Classic Case of Horrible Family Violence Where the Father Tried To Kill His Children - Dynamics of the Relationship between the Perpetrator and the Victim in Forensic Psychiatric Examination. J Foren Psy. 4:150. doi: 10.35248/2475-319X.19.4.150

Copyright: (C) 2019 Franjić S. This is an open-access article distributed under the terms of the Creative Commons Attribution License, which permits unrestricted use, distribution, and reproduction in any medium, provided the original author and source are credited. 
fear, or alarm in the community. Anyone who attempts to commit a crime may be dangerous, thus the community may incapacitate, deter, and punish such wrongdoers. Attempts, however, are generally punished less severely than the target offense; and if the target offense is consummated, the underlying attempt merges with the substantive offense.

The mental state required for an attempted crime is the specific intent to commit a particular offense formed in the mind of the defendant. This requirement is true even when the intended offense could have been committed with some lesser mental state such as recklessness.

\section{Child homicide}

Why are children the victims of their parents' inability to cope with life [4]? Are children expendable? What can stir a parent to kill a child, especially a newborn? People are horrified when parents kill their children, and the media focus varying amounts of attention on such crimes. Professionals and the lay public need to understand why these incidents occur and what family, medical, public agency, educational, and legislative actions can and should be undertaken to reduce them.

The primary finding is that there are significant commonalities in familicide offences where there was an apparent dispute about custody of, or access to the children [5]. Domestic violence was present in every case where details of the spousal relationship were known. The men were characterised by obsessiveness, lack of individuation and pathological jealousy, including jealousy of their own children. Egocentricity and threats to harm self and others were common. Most of these characteristics were universally present where detailed information about the nature of family relationships was accessible. Before the offence, there were obvious signs in the man's behaviour indicating deterioration in his mental health, which in turn affected his ability to cope with the separation.

Child killing within the family can be divided into three categories based on the age of the victim: neonaticide, infanticide, or filicide [4]. The murderer in these cases is usually one of the child's parents; occasionally, it is someone acting in loco parentis. Most of the books available focus on mothers who kill their children of any age; they seriously underestimate the number of father figures who commit infanticide and filicide.

If the baby's father was involved in the neonaticide, does that change the legal perspective? If he was not involved, should he be permitted to escape any penalty for his role in the pregnancy that led to the crime? The law varies among communities, as well as among states and nations; it has changed over the centuries and even over recent decades. Awareness of these variations is necessary to the construction of any new policies.

Many of these questions arise in cases of infanticide and filicide as well, with others added to the list. In an era when births are shown in almost complete detail in televised soap operas or "family" shows, there seems to be little excuse for anyone to be uninformed about infantile crying and bodily functions. What psychological factors operate to repress such knowledge in the minds of those who kill an infant for crying too long, too often, or at the "wrong" time? Social welfare agencies exist in virtually every community in the United States, so why are some parents so overwhelmed by child care that they murder a child rather than seek outside help?
In cases in which parents separate, why does one parent kill their offspring rather than provide child support or permit the other parent to have visitation or shared custody? Why are children the victims of their parents' inability to cope with life? Does postpartum depression or postpartum psychosis play a role in these crimes?

\section{Neonaticide}

Neonaticide is defined variously, in different jurisdictions, as the killing of an infant in the first 24 hours of life or the killing of an infant in the first 4 weeks of life [6]. In the forensic literature it is usually taken to mean the unlawful child killing of a subject delivered naturally and of sufficient developmental maturity to have been capable of independent survival, whose killing was perpetrated within the first 24 hours of life. Neonaticide by drowning is not rare, but it is, fortunately, decreasing in frequency in many Western societies. The syndrome is very specific and has been long recognized because of its sad sociofamilial overtones. In general, neonaticide is in almost always perpetrated by the mother. In some legal jurisdictions, the crime of neonaticide, with its connotations of diminished responsibility, is only recognized as a specific crime if perpetrated by the mother.

The mothers are almost always young (95 per cent of cases), often teenagers. They are almost always single. Neonaticide by drowning usually occurs in the context of a concealed pregnancy and in the context of a concealed, solitary labour and delivery. The mothers are often members of ethnic minority groups, often in religious or language isolates living in Western society. Such families typically are those with religious or traditional cultural condemnation of premarital sexual relations. These tragic incidents are also sometimes encountered in white or black families, particularly in those of lower socioeconomic status, in which there is a very strict, male-dominated ethos in the microsociety in which the parturient mother is trapped.

\section{Infanticide}

The crime of infanticide is the unlawful killing of a child under 1 year of age by its mother [6]. The designated crime of infanticide has evolved as the judicial recognition that there is a subset of unlawful killings that are the result of diminished responsibility.

The deliberate killing of an infant, by a mother often disabled by psychosis, occurs not at birth but in the weeks or months following birth. Under these circumstances, drowning is, in one sense, a non-specific modus, as the means of ending the child's life. Most such perpetrators are suffering from post-natal depression, with a smaller proportion afflicted with schizophrenia. The intra-family dynamics in cases of infanticide by immersion differ from those encountered in cases of the deliberative, repeated, sub-fatal trauma, which is a feature of the crescendo child abuse syndrome that, of course, may ultimately lead to the death of the child concerned.

\section{Filicide}

Filicide is that crime in which the offender is a biological, adoptive or de facto parent [6]. The method of killing is culture specific. In European, Asian, Canadian and Australasian societies the cause of such deaths are head injury, drowning or suffocation. In the United States, homicidal asphyxia is less common in some regions, where gunshot murder is more frequently employed. 
Mothers (60 per cent) kill their children more often than do fathers. Eighty per cent of such victims are between 1 and 5 years of age, with a median age of between 2 and 3 years. Particular 'at risk' times for such immersion killings are in the early hours of the evening, particularly during weekends.

\section{Cold case}

Cold case is a concept, and as such, there is no one standard definition of a cold case homicide [7]. These are those homicides that others, perhaps more experienced, tried to solve and could not. These are homicides previously reported to law enforcement and investigated, yet lacking resolution. These are cases in which a suspect may have been known to the investigators, yet there was insufficient evidence for arrest and charging. These also include those cases in which no perpetrator has been identified, and the case is a whodunit.

\section{Child injuries}

Non-accidental fractures in children are signs of the application of severe external force [8]. Hence, when non-accidental fractures are present, it is essential that they are identified as soon as possible.

Fractures inflicted by violence can be found throughout the whole skeleton, are often present in multiples and may be in various stages of healing. These stages are visible as such, and can be identified on skeletal radiographs. Also, dating makes it possible to show inconsistencies between the more or less objective radiological dating and the subjective anamnestic dating and the reason provided for the injury. Since in cases of abuse medical help is often sought late, further loading of the fracture by movement, additional injuries and newly sustained fractures may complicate the dating of an old fracture.

It is not always easy to differentiate between accidental and nonaccidental fractures; however, it is essential to do so in order to enable a responsible intervention. Adequate dating may help to establish whether the time given for the provided cause corresponds with the characteristics of the fracture.

When child abuse is suspected, it is important to pay attention to the patient history of the child and the other family members [8]. In case of child abuse it is possible that the child has sustained (multiple) previous trauma and has prior hospitalisations. Various studies have shown that approximately $50 \%$ of all children in which child abuse was established had been seen by a physician for (in retrospect suspect) injuries. Also, an abused child who returns to a non-safe home setting has a $30-50 \%$ chance to suffer additional trauma and an increased risk for lethal violence (up to10\%). Very regularly earlier trauma and hospitalisation are seen in other members of the family, such as the other parent, other children or between siblings. This may proof that the violence is also directed at them. When compared to other men, it appears that men who maltreat their wife will frequently also maltreat their children. Women who were abused by their husband appeared to be twice as likely to maltreat their children compared to non-abused women.

\section{Crime scene}

The solution of many crimes (and certainly all major ones) depends to a large extent on scientific support for the investigation team [9]. This can cover a wide spectrum of specialisms both inside and outside the police service, and includes the police surgeon. Initial crime scene examination is mainly carried out by police or civilian scene examiners supplemented by other experts where their specific knowledge and expertise is required. The formation of scientific support departments within police forces has varied greatly from force to force but most incorporate personnel responsible for photography, fingerprint, marks/impressions and forensic examination either as individual or multi-functional disciplines.

Detailed analysis of trace elements left at a scene by the perpetrator, and subsequent comparison with samples taken from a suspect will frequently solve a case; therefore it must be ensured that a complete and comprehensive examination of the scene is carried out and that all material seized is properly packaged and preserved for future analysis. The potential value of the information gained from such a careful examination is so important that those who have access to the scene for whatever purpose must appreciate the severe consequences of displaying a careless or haphazard attitude.

\section{Physical evidence}

Physical evidence is anything solid, liquid, or gas found at the crime scene that may be important to the case, and can establish that a crime has been committed or link a crime to the victim or draw a link between a crime a the perpetrator [10]. It can be found on the victim, on the suspect, and at the scene. It may be transferred to other objects or even other locations. Depending on the type of scene, the evidence, or the lack of expected evidence, may tell the investigator a great deal about the crime, the perpetrator, and the victim. The thorough and methodical search for evidence is key to the investigation, arrest, and conviction of the perpetrator.

Physical evidence may be very large or microscopic. It may be found in the environment, on the victim, or on the suspect. Remember, the lack of physical evidence may be just as important as the evidence itself. What you expect to see but don't could tell you a lot about the perpetrator.

Evidence is defined as all the means by which any alleged matter of fact whose truth is investigated at judicial trial is established or disproved [11]. Thus, evidence is essentially anything that is admitted into court or court preceding that can aid in proving or disproving some aspect of a crime or incident. Evidence can further be divided into four broad types: testimonial, demonstrative, circumstantial, and physical (real evidence).

Physical evidence aids in proving a crime has been in fact committed or provides key elements of the crime or incident. Physical evidence may be useful in placing the suspect at the scene or associating them with the victim. Physical evidence may aid in identifying those individuals associated with the crime. Physical evidence may be useful in exonerating the innocent or used to corroborate a victim's or witness' statement. Physical evidence is deemed more reliable than eyewitnesses to crimes. Recall that witness statements are more subjective than objective. Because of this, court decisions place more weight on physical evidence as opposed to witness statements and juries have come to expect physical evidence.

Unlike testimonial evidence, physical evidence is what it is. The human element (subjective nature) can be injected into the interpretation of physical evidence when the witness (the crime scene investigator, the expert witness, etc.) applies subjective interpretations to the physical evidence during the analysis and/ 
or testimony. In this case, the witness may be attempting to make a statement that is just not supported by the evidence.

\section{Child victims}

Victims of crimes arrive in hospital emergency departments (EDs) and may not be able to communicate with the health care providers due to physical injuries or language barriers [12]. One of the most valuable team members in the ED is a registered nurse who has also been trained in recognizing potential victims of elder abuse, sexual assault, psychological or child abuse, and more frequently, individuals who are under the control of human traffickers and domestic violence. Forensic nurses are also called on to document medical observations of subjects who may be victims of suspicious deaths, suicide/attempted suicide, or other such traumatic occurrences. Many victims are not willing to cooperate with police officers but will confide in nurses-and the professionally trained forensics nurse may be the key to gathering physical and biological evidence that leads to the arrest and conviction of someone who is preying on adult or child victims.

\section{Clinicians and courts}

Clinicians come from varied backgrounds, including social work, psychology, psychiatry, education, criminology, child welfare, nursing, and the clergy [13]. Broadly defined, clinicians provide psychotherapy, personal advice, information, emotional and social support, or problem-solving assistance to their clients. Some disciplines have strict requirements for licensing one to practice. However, many people who perform clinical services have no formal training and are not regulated under the auspices of a professional organization or a state licensing board.

\section{DISCUSSION}

In common parlance a witness is someone who has observed an event. Within the legal sphere a witness is someone who can provide proof of or attest to a fact or event. Sometimes, witnesses are asked to provide opinions rather than just facts. Witnesses present information in court and other adjudicative proceedings (i.e., processes in which information is presented to an individual or tribunal that has certain decision-making authority).

In forensic psychiatric examination it is important to establish the dynamics of the relationship between the perpetrator and the victim and the personality characteristics of the perpetrator [14]. Sanity will depend on the degree of disturbance of consciousness at the time of the offense, which is a very demanding judgment, since there are no objective, measurable indicators to monitor the quantity and intensity of consciousness disturbances.

\section{CONCLUSION}

A terrible story like this shocks every normal man. The ciminal law see this case as a fourfold murder attempt. Why has this happened, the key question to which answer must be given a criminal investigation? The punishment that follows for this monster will certainly not be small.

\section{REFERENCES}

1. Lazarov BD. A philosophy of criminal attempts. 2015; Cambridge University Press, Cambridge, UK, pp. 38-65.

2. Ohlin JD. Criminal Law - Doctrine, application, and practice. 2016; Wolters Kluwer, New York, USA, pp. 393.

3. Bacigal RJ. Criminal law and procedure - An overview. 2009; Delmar, Cengage Learning, Clifton Park, USA, pp. 41.

4. Schwartz LL, Isser NK. Child homicide - Parents who kill. 2007; CRC Press, Taylor \& Francis Group, Boca Raton, USA, pp. 42.

5. Johnson $\mathrm{CH}$. Come with daddy - Child murder-suicide after family breakdown. 2005; University of Western Australia Press, Crawley, Australia, pp. 131

6. Pearn J. Drowning and near drowning. 2008; CRC Press, Taylor \& Francis Group, Boca Raton, USA, pp. 352- 353.

7. Walton RH. The cold case problem. 2017; CRC Press, Taylor \& Francis Group, Boca Raton, USA, pp. 20.

8. Bilo RAC, Robber SGF, van Rijn RR. Forensic aspects of paediatric fractures - Differentiating accidental trauma from child abuse. 2010; Springer-Verlag, Berlin, Germany, pp. 189.

9. Hogg I. Scenes of crime. 2009; Cambridge University Press, Cambridge, UK, pp. 171

10. DuPre DMP. Homicide investigation field guide. 2013; Academic Press, Elsevier, Oxford, UK, pp. 27.

11. Baxter E. Complete crime scene investigation handbook. 2015; CRC Press, Taylor \& Francis Group, Boca Raton, USA, pp. 221-222.

12. Fish JT, Miller LS, Braswell MC, Wallace Jr EW. Crime scene investigation. 2014; Anderson Publishing, Elsevier Inc., Oxford, UK, pp. 7.

13. Barsky AE, Gould JW. Clinicians in Court - A guide to subpoenas, depositions, testifying, and everything else you need to know. 2002; The Guilford Press, New York, USA, pp. 1-2.

14. Pavišić B, Modly D, Veić P. Kriminalistika - Knjiga 2 (Criminalistics - Book 2). 2012; Dušević \& Kršovnik d.o.o., Rijeka, Croatia, pp. 23. 